\title{
A new species of Calonectria causing leaf blight and cutting rot of three forest tree species in Brazil
}

\author{
Rafael F. Alfenas ${ }^{1,3}$, Olinto L. Pereira', Vanessa L. Jorge ${ }^{1}$, Pedro W. Crous ${ }^{2}$ \& Acelino C. Alfenas ${ }^{1}$ \\ ${ }^{1}$ Departamento de Fitopatologia, Universidade Federal de Viçosa, 36570-000, Viçosa, MG, Brazil; ${ }^{2}$ CBS-KNAW Fungal \\ Biodiversity Centre, Uppsalalaan 8, 3584 CT, Utrecht, The Netherlands; ${ }^{3}$ Clonar Resistência a Doenças Florestais, CENTEV, \\ 36570-000, Viçosa, MG, Brazil
}

Author for correspondence: Olinto L. Pereira, e-mail: oliparini@ufv.br

\begin{abstract}
Several species of Calonectria cause diseases on a wide range of forest tree species that are propagated either via seedlings or rooted cuttings. In nurseries these fungi cause damping-off, cutting and root rots, stem lesions, and leaf blights. Recently a Calonectria sp. was isolated from rooted cuttings of Anadenanthera peregrina (Fabaceae), Piptadenia gonoacantha (Fabaceae), and Azadirachta indica (Meliaceae) exhibiting leaf blight and cutting rot in a forest nursery at the Universidade Federal de Viçosa, Brazil. Morphological comparisons and DNA sequences of three loci containing partial gene sequences of $\beta$-tubulin (TUB2), calmodulin (CAL), and elongation factor (TEF-1 $\alpha$ ) indicated that these isolates represent an unnamed species of Calonectria, described here as C. hodgesii sp. nov. Sprayinoculated plants of all three hosts with a suspension at $1 \times 10^{4}$ conidia $\mathrm{mL}^{-1}$ induced leaf lesions, cutting rot, and intense defoliation as observed under natural conditions. Calonectria hodgesii was re-isolated from infected tissue, which fulfilled Koch's postulates and confirmed its status as a pathogen with a wide host range.
\end{abstract}

Key words: forest pathology, Hypocreales, pathogenicity, phylogeny, taxonomy, tropical fungi.

\section{INTRODUCTION}

In recent years there has been an increasing demand for planting forest tree species in Brazil, in part due to the government's initiatives to restore degraded areas and mitigate global warming. Anadenanthera peregrina (L.) Speg. (Angico Vermelho) and Piptadenia gonoacantha (Mart.) J.F. Macbr. (Pau-Jacaré) are among the most commonly used native species (Carvalho, 1994; Araújo et al., 2006). There has also been an increase in plantations of Azadirachta indica A. Juss. (Neem), which is native to India. The increased planting of $A$. indica is largely due to its multiple applications in the pharmaceutical industry, use in agriculture as a natural insecticide, and more recently for biodiesel production (Mossini \& Kemmelmeier, 2005). Nevertheless, propagation of these species either via cuttings or seedlings is generally still done in nurseries with low technology, where appropriate management practices for disease control are not employed (Mafia et al., 2007).

Numerous pathogenic fungal species, especially species of Calonectria, have been described from forest nurseries and have been reported as pathogens of a wide range of plant hosts cultivated via seedlings or vegetative propagation (Crous, 2002). Among the major nursery diseases, damping-off, cutting rot, stem girdling and leaf blight caused by Calonectria spp. are commonly encountered (Hodges \& May, 1972; Lombard et al., 2010a). In recent years several new species of Calonectria have been newly described from hosts in forestry nurseries using a polyphasic approach incorporating morphological and molecular data (Lombard et al., 2010c; Alfenas et al., 2013).

Because of the importance of the genus Calonectria as plant pathogen in tropical and subtropical climates, we have for the past two years been collecting plant and soil samples from different hosts throughout Brazil to facilitate population biology studies of Calonectria spp.

During one these collecting in the Forest Nursery at the Universidade Federal de Viçosa, Brazil, in May 2011, we found rooted cuttings of $A$. peregrina, $A$. indica and $P$. gonoacantha exhibiting necrotic leaf blight, defoliation and cutting rot symptoms with brown and necrotic tissues at the stem base, covered by profuse white sporulation typical of Calonectria infection (Figure 1). The same symptoms were observed on all three hosts. The primary aim of this study was to identify the causal agent of this disease through a combination of morphological and molecular characterization, and pathogenicity tests.

\section{MATERIAL AND METHODS}

\section{Isolates}

Single conidial isolates of a Calonectria sp. were obtained from leaves and cuttings of infected plants of $A$. peregrina, $A$. indica and $P$. gonoacantha.

To obtain single conidial cultures, pathogen structures observed under a stereoscopic microscope (45 

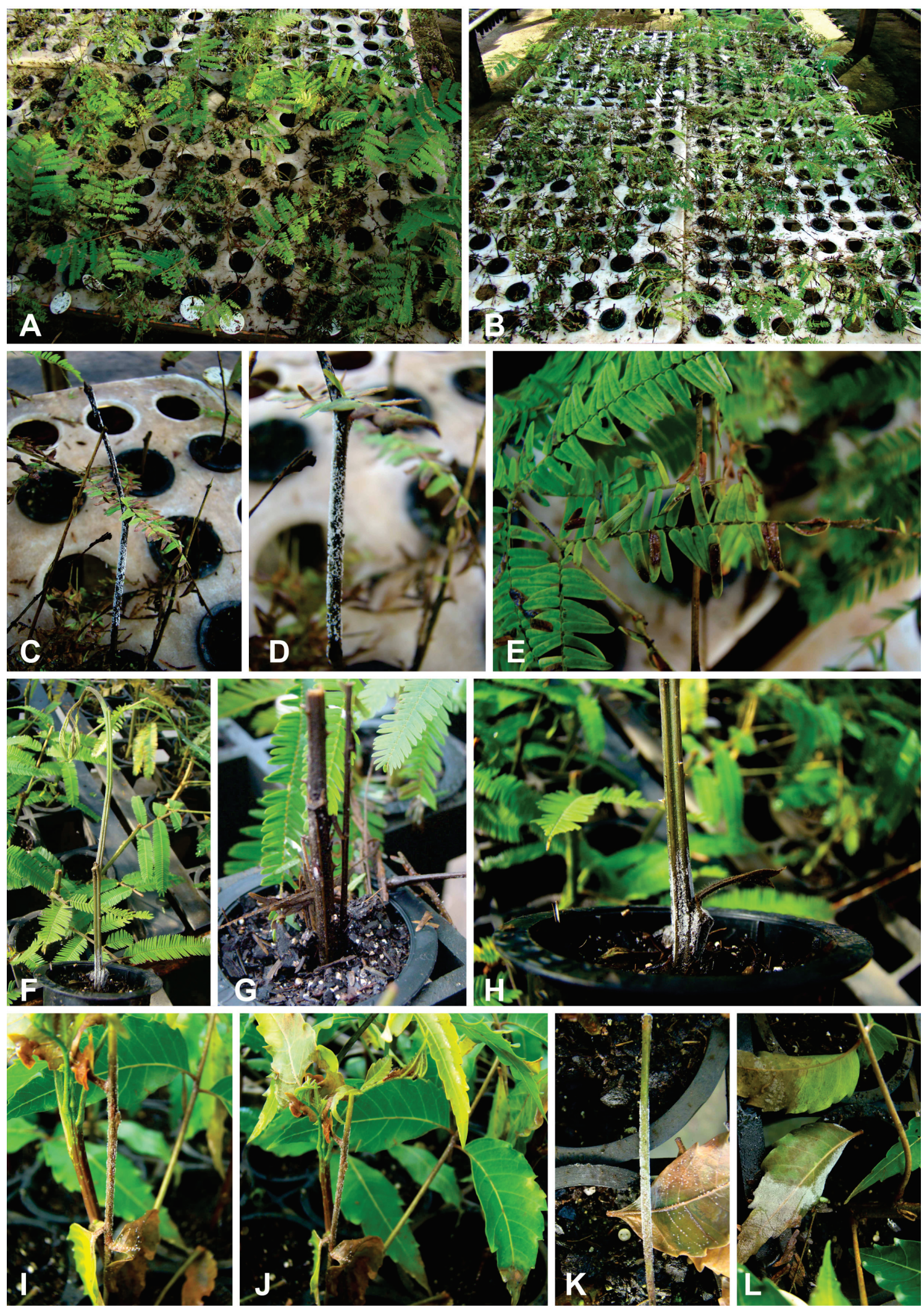

FIGURE 1 - Leaf blight and cutting rot caused by Calonectria hodgesii on rooted cuttings of forest species in a nursery. A,B: General view containing infected rooted cuttings of Anadenanthera peregrina and Piptadenia gonoacantha; C-E: Cutting rot and leaf blight in A. peregrina; F-H: Cutting rot in P. gonoacantha; I-L: Cutting rot and leaf blight with intense sporulation on seedlings of Azadirachta indica. 
$\mathrm{x})$ were deposited on Petri dishes containing water agar medium [WA, $1.5 \%(\mathrm{w} / \mathrm{v})$ agar]. Subsequently $2 \mathrm{~mL}$ of sterile distilled water were added to each WA dish, and shaken manually. Excess water was removed by inverting the Petri dish, and under a stereomicroscope $(45 \mathrm{x})$ a single conidium was transferred to a Petri dish containing malt extract agar (MEA). Plates were maintained at $26^{\circ} \mathrm{C}$ for 5 days to promote fungal growth. One representative isolate from each host was selected for further studies. To maintain viable isolates strains were stored in a glycerol solution $(10 \%)$ at $-80^{\circ} \mathrm{C}$.

\section{DNA extraction and amplification}

Mycelia of the respective isolates were scraped from colonized MEA plates, and placed separately in $2 \mathrm{~mL}$ microtubes for genomic DNA extraction using the Wizard Genomic DNA Purification (Promega) kit. For PCR, the DreamTaq Master Mix (Fermentas) was used, following the manufacturer's protocol.

Three loci, including fragments of the $\beta$-tubulin (TUB2), calmodulin (CAL), and elongation factor (TEF$1 \alpha)$ gene regions were amplified using the primers T1 (O'Donnell \& Cigelnik, 1997) and CYLTUB1R (Crous et al., 2004) for TUB2, CAL-228F and CAL-737R (Carbone \& Kohn, 1999) for CAL, and EF1-728F (O'Donnell et al., 1998) and EF-2 (Carbone \& Kohn, 1999) for TEF-1 $\alpha$. Amplification was performed with an initial denaturing at $96^{\circ} \mathrm{C}$ for $5 \mathrm{~min}$ followed by 35 cycles of denaturation at $96^{\circ} \mathrm{C}$ for $30 \mathrm{~s}$, annealing at $52^{\circ} \mathrm{C}$ for $30 \mathrm{~s}$, extension at $72^{\circ} \mathrm{C}$ for $1 \mathrm{~min}$ and a final $4 \mathrm{~min}$ extension at $72^{\circ} \mathrm{C}$. The PCR product was visualized on a $2 \%$ agarose gel to determine fragment size and purity. PCR products were prepared for sequencing with the ExoSAP-IT kit (Affymetrix) according to the manufacturer's protocol.

\section{Sequencing and phylogenetic analyses}

Sequencing was performed at the Laboratory of Genomics of the Instituto de Biotecnologia Aplicada à Agropecuária (BIOAGRO) at the Universidade Federal de Viçosa, Brazil. Sequence quality was checked via Sequence Scanner Software v. 1.0 (Applied Biosystems), and edited using the software package Seqman from DNAStar Inc. Consensus regions of edited sequences were compared in the NCBI GenBank nucleotide database (www.ncbi.nlm.nih.gov) using the nucleotide collection (nr/nt) optimised for highly similar sequences (megablast). Calonectria sequences generated in this study were deposited in GenBank (Table 1). All sequences were assembled in MAFFT v. 6 (Katoh \& Toh, 2010), using the FFT-NS-i (Slow; iterative refinement method) alignment strategy with the 200PAM/ K=2 scoring matrix and a gap opening penalty of 1.53 with an offset value of 0.0. Aligned sequences were then manually corrected when necessary using MEGA v. 5 (Tamura et al., 2011).

PAUP (Phylogenetic Analysis Using Parsimony, v. 4.0b10; Swofford, 2002) was used to analyse the DNA sequence datasets. A partition homogeneity test (Farris et al., 1994) was applied to determine whether the data sets were consistent and combinable. Phylogenetic relationships were estimated by heuristic searches based on 1,000 random addition sequences and tree bisection-reconnection, with the branch swapping option set on 'best trees' only. All characters were weighed equally and alignment gaps were treated as missing data. Measures calculated for parsimony included tree length (TL), consistency index (CI), retention index (RI) and rescaled consistence index (RC). Bootstrap analyses (Hillis \& Bull, 1993) were based on 1,000 replications.

Analysis of Bayesian Inference (BI) was performed with MrBayes v. 3.1.1 (Ronquist \& Heulsenbeck, 2003) using the algorithm of Markov Chain Monte Carlo (MCMC) with two sets of four chains (one cold and three heated) with 10 million random generations. The sample frequency was set to 1,000 and the first $25 \%$ of trees were removed as burnin. Likelihood values were calculated and the best model of nucleotide substitution for each gene was selected according to the Akaike Information Criterion (AIC) using MrModeltest v. 2.3 (Posada \& Buckley, 2004).

The convergence of the log likelihood was analysed using TRACER v. 1.5 (Rambaut \& Drummond, 2009) and no indication of lack of convergence was detected. Calonectria chinensis (Crous) L. Lombard, M. J. Wingf. $\&$ Crous was used as outgroup in the analysis.

\section{Morphological characterization}

For morphological characterization single conidial cultures were grown in synthetic nutrient-poor agar (SNA) at $26^{\circ} \mathrm{C}$ for 7 days. Fungal structures were mounted in clear lactic acid for morphological examination, and 30 measurements of each structure determined at 1,000 $\times$ magnification using a Zeiss Axioscope-2 microscope with differential interference contrast (DIC) illumination. The 95\% confidence levels were determined and extremes of conidial measurements are given in parentheses. For other structures, only extremes are presented.

\section{Pathogenicity test}

Single conidial cultures were transferred aseptically to Petri dishes (90 $\mathrm{mm}$ diam) containing Malt Extract Agar (MEA), and subsequently incubated at $26^{\circ} \mathrm{C}$ for 10 days for pathogenicity studies. Healthy rooted cuttings (five per species) of $A$. peregrina, $A$. indica and $P$. gonoacantha were spray-inoculated with a conidial suspension of $1 \times 10^{4}$ conidia $\mathrm{mL}^{-1}$ of each isolate, as described by Graça et al. (2009). Five plants of each host species were treated with distilled water to serve as controls. The inoculated plants were maintained in a greenhouse under controlled conditions $\left(25^{\circ} \mathrm{C} \pm 3^{\circ} \mathrm{C}\right)$ and the development of symptoms was monitored daily for 10 days, after which time the fungus was re-isolated from the lesion margins. 


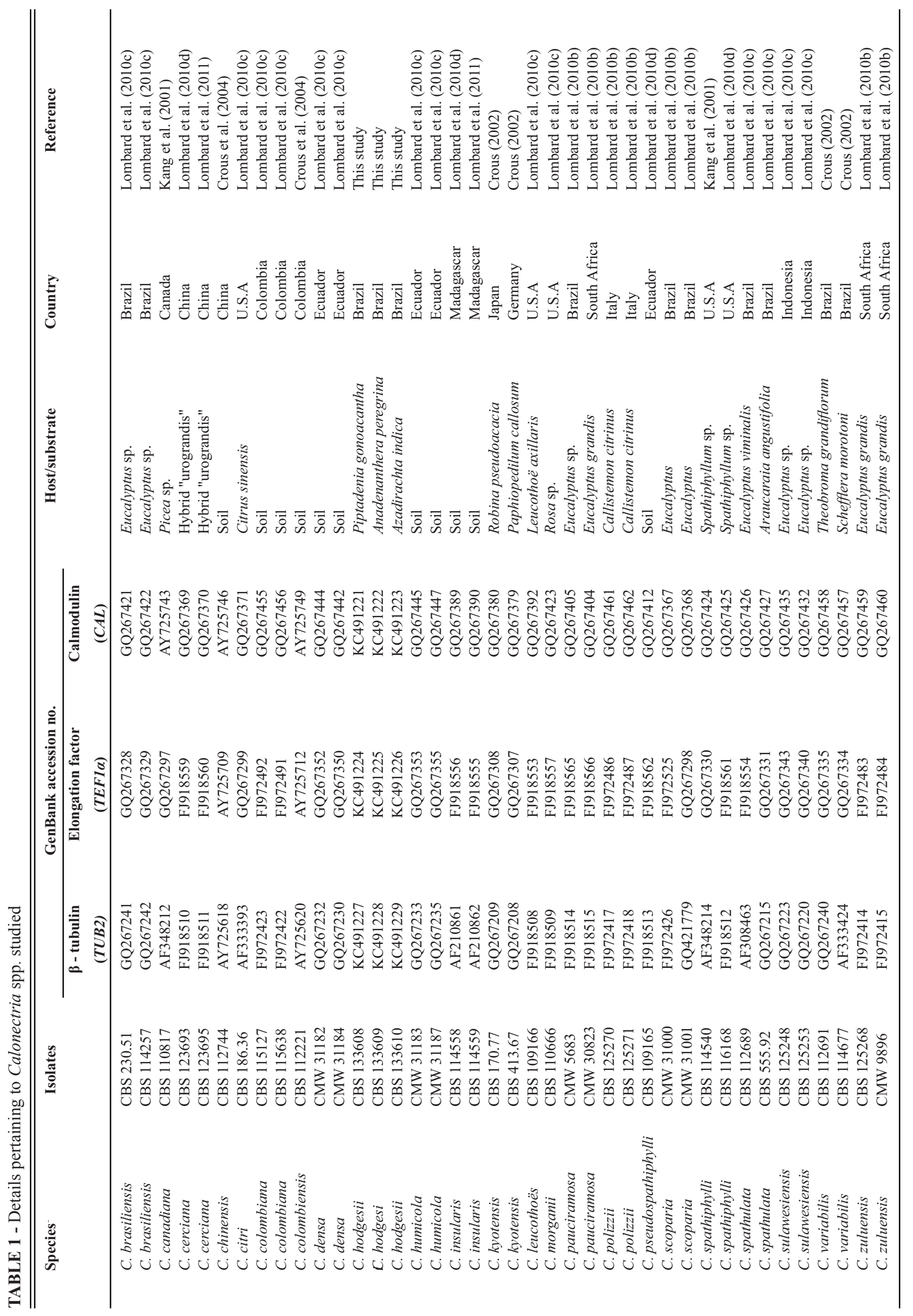




\section{RESULTS}

\section{Phylogenetic analysis}

Amplicons of approximately 500 bases each for TUB2, TEF-1 $\alpha$, and CAL were generated. The $70 \%$ reciprocal bootstrap trees showed no conflict in tree topologies for the three gene regions separately, and therefore they were combined in a dataset consisting of 1,531 characters including gaps. Of these 1,100 were constant and parsimony uninformative and 431 were parsimony informative. Analysis of the 431 parsimony informative characters yielded three equally most parsimonious trees $(\mathrm{TL}=1033 \mathrm{CI}=0.691, \mathrm{RI}=0.871, \mathrm{RC}=0.602)$. Evolution models HKY + G for TUB2, TEF, and CAL were selected and incorporated into the Bayesian analysis. The consensus tree obtained for the Bayesian analyses confirmed the tree topology obtained with parsimony. The isolates of Calonectria from $A$. peregrina, $A$. indica and $P$. gonoacantha formed a distinct, well-supported clade $(\mathrm{PP}=1,00)$ (Figure 2).

\section{Taxonomy}

Based on the DNA sequence data and morphological features, we conclude that the Calonectria isolates from $A$. peregrina, $A$. indica and $P$. gonoacantha represent a novel species, which is described below:

Calonectria hodgesii R.F. Alfenas, O.L. Pereira, Crous \& Alfenas, sp. nov. MycoBank MB 803943 (Figure 3);

Etymology: Named after Dr. Charles S. Hodges, in honor of his contribution to forest pathology in the tropics;

Hosts: Anadenanthera peregrina, Azadirachta indica and Piptadenia gonoacantha;

Specimen examined: Brazil, Minas Gerais state, Viçosa, on Anadenanthera peregrina, May 2011, Rafael F. Alfenas (Holotype CBS H-21147, Culture ex-type CBS 133609).

Conidiophores containing a stipe bearing penicillate suites of fertile branches, stipe extensions, and terminal vesicles; stipe septate, hyaline, smooth, 40-82 × 5-7 $\mu \mathrm{m}$; stipe extensions septate, straight to flexuous 136-196 $\mu \mathrm{m}$ long, 2-4 $\mu \mathrm{m}$ wide at the apical septum, terminating in pyriform to ellipsoidal or ovoid to sphaeropedunculate vesicles, 6-11 $\mu \mathrm{m}$ diam. Conidiogenous apparatus 45$65 \mu \mathrm{m}$ long, 61-72 $\mu \mathrm{m}$ wide at apex; primary branches aseptate, $18-27 \times 4-5 \mu \mathrm{m}$; secondary branches aseptate, 12 $24 \times 3-4 \mu \mathrm{m}$, and tertiary branches aseptate, 9-18 $\times 3-5 \mu \mathrm{m}$, each terminal branch producing 2-6 phialides; phialides doliiform to reniform, hyaline, 5-10 × 2-4 $\mu$ m; apex with minute periclinal thickening and inconspicuous collarette. Macroconidia cylindrical, rounded at both ends, straight, (4449-51(-55) × 3-5 $\mathrm{m}(\mathrm{av} .=50 \times 4.5 \mu \mathrm{m}), 1$-septate, lacking a visible abscission scar, held in parallel cylindrical clusters by colourless slime. Mega- and microconidia not seen.

Notes: Calonectria hodgesii is phylogenetically closely related to $C$. brasiliensis and $C$. sulawesiensis, but
C. hodgesii can easily be distinguished from these species based on the size of its macroconidia, vesicle shape, number of macroconidiophore branches, and DNA sequence data.

Culture characteristics: Colonies sienna to umber on the surface and sepia to brown-vinaceous in reverse, with moderate aerial mycelium; chlamydospores moderate to extensive, occurring throughout the colony, forming microsclerotia; extensive sporulation on the aerial mycelium; moderate to rapid growth $(50-65 \mathrm{~mm})$ diam after 7 days at $25^{\circ} \mathrm{C}$ on MEA.

\section{Pathogenicity test}

After 10 days spray-inoculated plants showed necrotic leaf blight, cutting rot with brown and necrotic tissues of the basal stem, and intense defoliation as observed under natural conditions in the nursery. Profuse sporulation was also observed on necrotic lesions of inoculated organs of all three host species.

\section{DISCUSSION}

In the present study we describe a new species of Calonectria associated with necrotic leaf blight and cutting rot of $A$. peregrina, $A$. indica and $P$. gonoacantha in Brazil based on morphological and molecular data. Calonectria hodgesii formed a distinct and well-supported phylogenetic clade, closely related to C. brasiliensis and C. sulawesiensis, which belong to the $C$. morganii species complex. This complex, characterised by having uniseptate macroconidia and vesicles varying from pyriform to obpyriform or ovoid to ellipsoidal, includes $C$. cerciana L. Lombard, M.J. Wingf. \& Crous, C. insularis C.L. Schoch \& Crous, C. morganii, C. sulawesiensis, C. hawksworthii (Peerally) L. Lombard, M.J. Wingf. \& Crous, C. leucothöes (El-Gholl, Leahy \& T.S. Schub.) L. Lombard, M.J. Wingf. \& Crous, C. variabilis Crous, B.J.H. Janse, D. Victor, G.F. Marias \& Alfenas and C. brasiliensis (Peerally) L. Lombard, M.J. Wingf. \& Crous (Schoch et al., 2001; Lombard et al., 2010c).

Calonectria hodgesii is characterised by having macroconidia larger than those of $C$. brasiliensis, $C$. morganii and $C$. sulawesiensis, but smaller than $C$. variabilis (Table 2). Superficially $C$. hodgesii resembles C. variabilis in having vesicles that vary in shape, and it is quite probable that many isolates previously identified as $C$. variabilis, were in fact representative of $C$. hodgesii. The two species can be distinguished, however, in that C. hodgesii has 1-septate conidia, while C. variabilis has (1-)3(-4)-septate conidia. Although the vesicle shape of C. hodgesii is also quite variable, it is mainly obpyriform to ellipsoidal, while those of $C$. variabilis vary from clavate to ellipsoidal. Interestingly, the new species shares morphological characteristics with phylogenetically distant species, such as Calonectria citri (H.S. Fawc. \& Klotz) L. Lombard, M.J. Wingf. \& Crous and Calonectria canadiana L. Lombard, M.J. Wingf. \& Crous. 


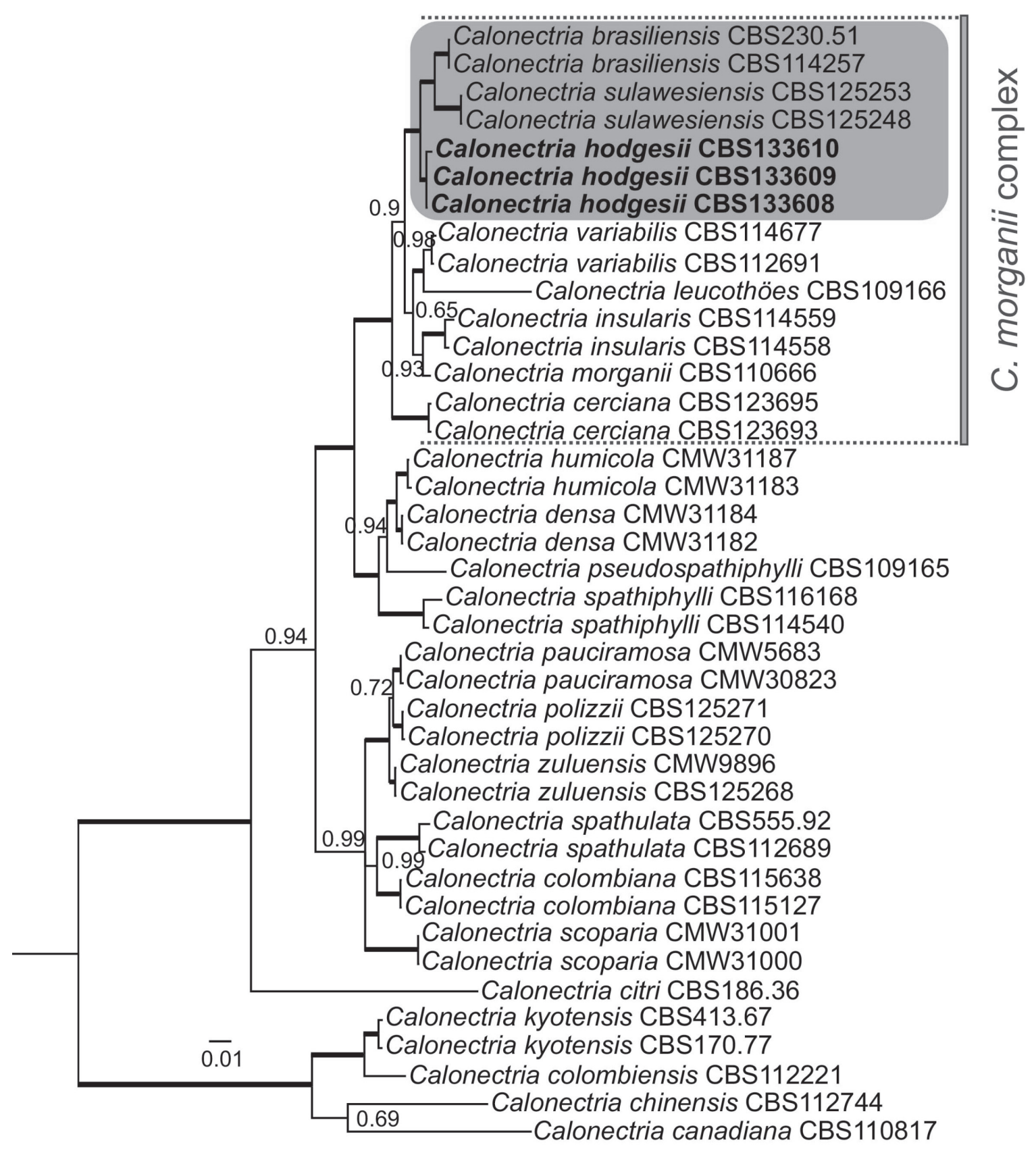

FIGURE 2 - Phylogenetic tree obtained from Bayesian inference using combined sequences of the $\beta$-tubulin, translation elongation factor- $1 \alpha$ and calmodulin genes of Calonectria isolates. The bold lines indicate posterior probability values of 1.00. The tree was rooted to C. chinensis (CBS 112744). Isolates in bold were obtained during the survey.

Species of the C. morganii complex are well-known pathogens of various hosts worldwide (Crous, 2002), and some, like $C$. brasiliensis, are known to be highly aggressive to Eucalyptus seedlings (Batista, 1951). Originally, C. brasiliensis was described as a variety of C. morganii Crous, Alfenas \& M.J. Wingf. (as Cylindrocladium scoparium var. brasiliensis Batista \& Ciferri) based on having macroconidia smaller than those of Calonectria morganii (Batista, 1951;
Peerally, 1974). Based on morphological characteristics and total protein banding patterns however, Crous et al. (1993a) reduced $C$. brasiliensis to synonymy under $C$. morganii. By employing multigene DNA sequence data, Lombard et al. (2010b) recently showed that the ex-type culture of C. brasiliensis (CBS 230.51) is phylogenetically and morphologically distinct from C. morganii, and therefore reinstated it to species level. 

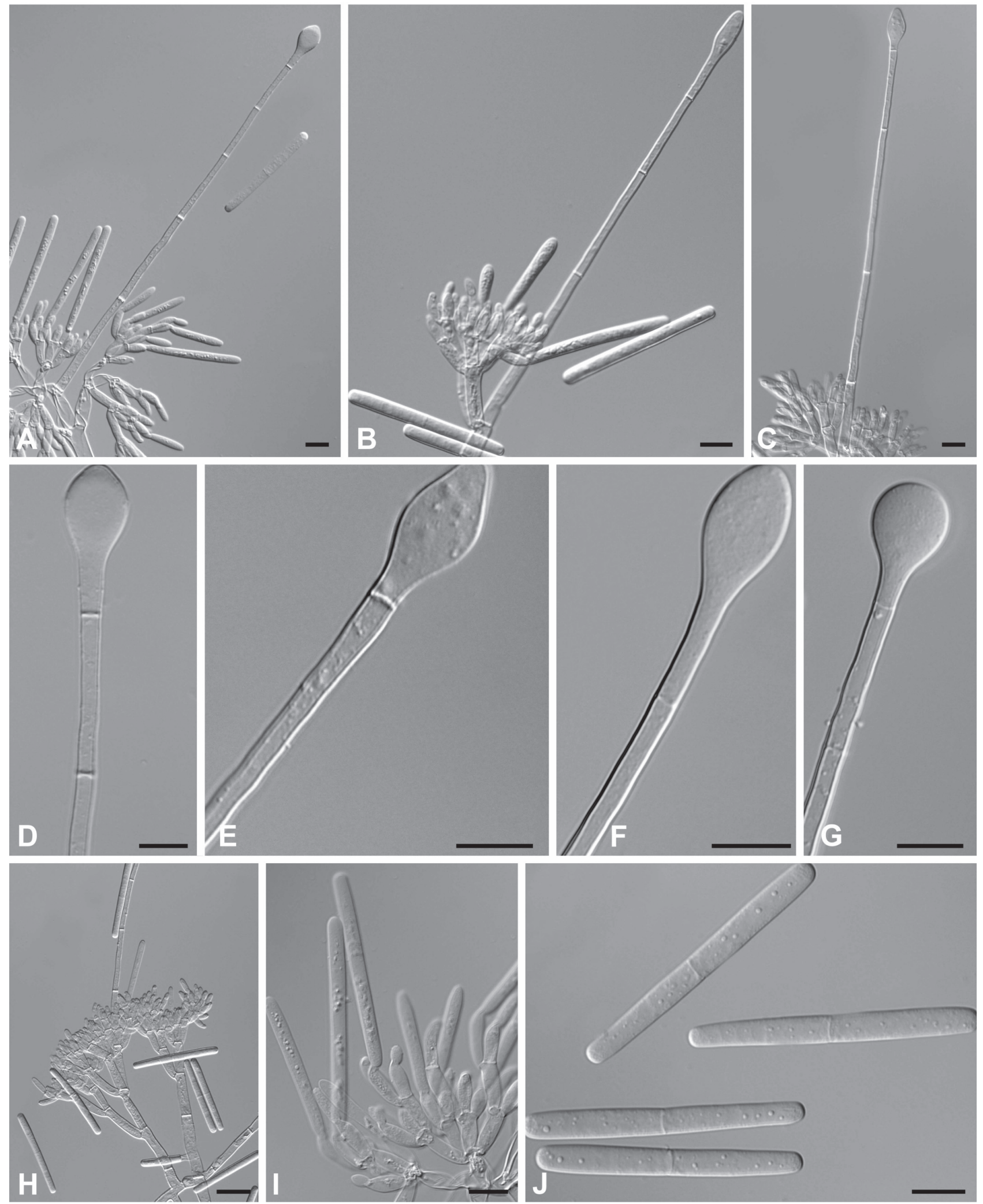

FIGURE 3 - Morphological characteristics of Calonectria hodgesii. A-C: Macroconidiophores containing obpyriform to ellipsoidal or sphaeropedunculate vesicles; D-G: Variation in vesicle shape; H, I: Macroconidiophores; J: Uniseptate macroconidia. Scale bars = $10 \mu \mathrm{m} ; \mathrm{H}=20 \mu \mathrm{m}$. 
TABLE 2 - Distinctive morphological characters of Calonectria hodgesii and related species

\begin{tabular}{|c|c|c|c|c|}
\hline Species & Vesicle shape & $\begin{array}{c}\text { Vesicle } \\
\text { diameter }\end{array}$ & $\begin{array}{l}\text { Macroconidial } \\
\text { size }\end{array}$ & $\begin{array}{c}\text { Macroconidial } \\
\text { septation }\end{array}$ \\
\hline C. brasiliensis ${ }^{\mathbf{a}}$ & ellipsoidal to obpyriform & $7-11 \mu \mathrm{M}$ & $(35-) 38(-41) \times 3-5 \mu \mathrm{M}$ & 1-septate \\
\hline C. canadiana $^{\mathbf{b}}$ & pyriform to sphaeropedunculate & $6-10 \mu \mathrm{M}$ & $(38-) 50(-65) \times 4-5 \mu \mathrm{M}$ & 1-septate \\
\hline C. citri $^{\mathbf{c}}$ & obovoid to spathulate & $6.5-10 \mu \mathrm{M}$ & $(50-) 57.5(-65) \times 3-4 \mu \mathrm{M}$ & (1-)3-septate \\
\hline C. hodgesii & $\begin{array}{l}\text { ellipsoidal to pyriform, or ovoid to } \\
\text { sphaeropedunculate }\end{array}$ & $6-11 \mu \mathrm{M}$ & $(44-) 50(-55) \times 3-5 \mu \mathrm{M}$ & 1-septate \\
\hline C. morganii ${ }^{\mathbf{d}}$ & clavate, ellipsoid to pyriform & $6-8 \mu \mathrm{M}$ & $(40-) 45(-66) \times 3-5 \mu \mathrm{M}$ & 1-septate \\
\hline C. sulawesiensis ${ }^{\mathbf{e}}$ & broadly clavate to ellipsoidal & $5-7 \mu \mathrm{M}$ & $(41-) 48(-54) \times 3-6 \mu \mathrm{M}$ & 1-septate \\
\hline C. variabilis ${ }^{\mathbf{d}}$ & $\begin{array}{l}\text { sphaeropedunculate to ovoid, or } \\
\text { ellipsoid to clavate }\end{array}$ & $6-11 \mu \mathrm{M}$ & $(48-) 73(-85) \times 4-6 \mu \mathrm{M}$ & $(1-) 3(-4)$-septate \\
\hline
\end{tabular}

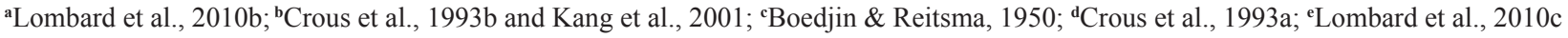

Calonectria sulawesiensis Lombard et al. (2010c), described from Eucalyptus sp. in Indonesia, is another phylogenetically closely related species, but it is morphologically distinct, and presently nothing is yet known regarding its pathogenicity and host range.

In our studies all three selected isolates (CBS133608, CBS133609, and CBS133610) of C. hodgesii tested were pathogenic, and induced leaf blight, defoliation and cutting rot in $A$. peregrina, $A$. indica and $P$. gonoacantha similar to that observed in the nursery under natural conditions.

The occurrence of $C$. hodgesii sp. nov. causing leaf blight and cutting rot on these hosts represents an alert for nurseries that propagate these forest species either from seedlings or rooted cuttings.

\section{ACKNOWLEDGMENTS}

We thank the Departamento de Fitopatologia of Universidade Federal de Viçosa and CBS-KNAW Fungal Biodiversity Centre for financial and technical support to undertake this study. This work was also supported by Coordenação de Aperfeiçoamento de Pessoal de Nível Superior - CAPES, Conselho Nacional de Desenvolvimento Científico e Tecnológico - CNPq, and Fundação de Amparo à Pesquisa de Minas Gerais - FAPEMIG. The first author is grateful to Dr. Lorenzo Lombard for advice regarding the morphological characterization of $C$. hodgesii, to Dr. Charles S. Hodges for reviewing the latest version of this manuscript, and to Drs. J.Z. (Ewald) Groenewald and Danilo Batista Pinho for advice regarding DNA sequence analyses.

\section{REFERENCES}

Alfenas RF, Pereira OL, Ferreira MA, Jorge VL, Crous PW, Alfenas AC (2013) Calonectria metrosideri, a highly aggressive pathogen causing leaf blight, root rot, and wilt of Metrosideros spp. in Brazil. Forest Pathology 43:257-265

Araújo FS, Martins SV, Meira Neto JAA, Lanis JLL, Pires IE (2006) Estrutura da vegetação arbustivo-arbórea colonizadora de uma área degradada por mineração de caulim, Brás Pires, MG. Revista Árvore 30:107-116.

Batista AC (1951) Cylindrocladium scoparium Morgan var. brasiliensis Batista \& Ciferri, um novo fungo sobre Eucalyptus. Boletim da Secretaria de Agricultura, Indústria e Comércio do Estado de Pernambuco 18:188-181.

Boedijn KB, Reitsma J (1950) Notes on the genus Cylindrocladium. Reinwardtia 1:51-60.

Carbone I, Kohn LM (1999) A method for designing primer sets for speciation studies in filamentous Ascomycetes. Mycologia 91:553-556.

Carvalho PER (1994) Espécies florestais brasileiras: Recomendações silviculturais, potencialidades e uso da madeira. Brasília DF. Embrapa CNPF.

Crous PW (2002) Taxonomy and pathology of Cylindrocladium (Calonectria) and allied genera. St. Paul MN, USA. APS Press.

Crous PW, Groenewald JZ, Risede J-M, Simoneau P, HywelJones NL (2004) Calonectria species and their Cylindrocladium anamorphs: Species with sphaeropedunculate vesicles. Studies in Mycology 50:415-430.

Crous PW, Alfenas AC, Wingfield MJ (1993a) Calonectria scoparia and Calonectria morganii sp. nov., and variation among isolates of their Cylindrocladium anamorphs. Mycological Research 97:701-708.

Crous PW, Janse BJH, Victor D, Marais GF, Alfenas AC (1993b) Molecular characterization of Cylindrocladium spp. with threeseptate conidia and ovoid-like vesicles. Systematic and Applied Microbiology 16:266-273.

Farris JS, Källersjö M, Kluge AG, Bult C (1994) Testing significance of incongruence. Cladistics 10:315-320.

Graça RN, Alfenas AC, Maffia LA, Titon M, Alfenas RF, Lau D, Rocabado JMA (2009) Factors influencing infection of eucalypts by Cylindrocladium pteridis. Plant Pathology 58:971-981.

Hillis DM, Bull JJ (1993) An empirical test of bootstrapping as a method for assessing confidence in phylogenetic analysis. Systematic Biology 42:182-192.

Hodges CS, May LC (1972) A root disease of pine, araucaria, and eucalyptus in Brazil caused by a new species of Cylindrocladium. Phytopathology 62:898-901. 
Kang JC, Crous PW, Schoch CL (2001) Species concepts in the Cylindrocladium floridanum and Cy. spathiphylli complexes (Hypocreaceae) based on multiallelic sequence data, sexual compatibility and morphology. Systematic and Applied Microbiology 24:206-217.

Katoh K, Toh H (2010) Parallelization of the MAFFT multiple sequence alignment program. Bioinformatics 26:1899-1900.

Lombard L, Crous PW, Wingfield BD, Wingfield MJ (2010a) Species concepts in Calonectria (Cylindrocladium). Studies in Mycology 66:1-14.

Lombard L, Crous PW, Wingfield BD, Wingfield MJ (2010b) Multigene phylogeny and mating tests reveal three cryptic species related to Calonectria pauciramosa. Studies in Mycology 66:1530.

Lombard L, Crous PW, Wingfield BD, Wingfield MJ (2010c) Phylogeny and systematics of the genus Calonectria. Studies in Mycology 66:31-69.

Lombard L, Zhou XD, Crous PW, Wingfield BD, Wingfield MJ (2010d) Calonectria species associated with cutting rot of Eucalyptus. Persoonia 24:1-11.

Mafia RG, Alfenas AC, Resende Júnior MFR (2007) Damping-off of forest species caused by Sclerotium rolfsii Sacc. Revista Árvore 31:629-634.

Mossini SAG, Kemmelmeier C (2005) A árvore nim (Azadirachta indica. A. Juss.): Múltiplos usos. Acta Farmaceutica Bonaerense 24:139-148.

O’Donnell K, Cigelnik E (1997) Two divergent intragenomic rDNA ITS2 types within a monophyletic lineage of the fungus
Fusarium are nonorthologous. Molecular Phylogenetics and Evolution 7:103-116.

O’Donnell K, Kistler HC, Cigelnik E, Ploetz RC (1998) Multiple evolutionary origins of the fungus causing Panama disease of banana: Concordant evidence from nuclear and mitochondrial gene genealogies. Proceedings of the National Academy of Sciences, USA 95:2044-2049.

Peerally A (1974) Cylindrocladium braziliensis. CMI Descriptions of Pathogenic Fungi and Bacteria No. 427. Kew UK. CMI/AAB.

Posada D, Buckley TR (2004) Model selection and model averaging in phylogenetics: Advantages of Akaike Information Criterion and Bayesian approaches over likelihood ratio tests. Systematic Biology 53:793-808.

Rambaut A, Drummond AJ (2009) Tracer v1.5: Available at: http:// beast.bio.ed.ac.uk/Tracer. Accessed on September 05, 2012.

Ronquist F, Huelsenbeck JP (2003) MrBayes 3: Bayesian phylogenetic inference under mixed models. Bioinformatics 19:1572-1574.

Schoch CL, Crous PW, Wingfield BD, Wingfield MJ (2001) Phylogeny of Calonectria based on comparisons of $\beta$-tubulin DNA sequences. Mycological Research 105:1045-1052.

Swofford DL (2002) PAUP*. Phylogenetic Analysis Using Parsimony (*and other methods). 4.0b10. Sunderland MA, USA. Sinauer Associates.

Tamura K, Peterson D, Peterson N, Stecher G, Nei M, Kumar S (2011) MEGA5: Molecular evolutionary genetics analysis using Maximum Likelihood, Evolutionary Distance, and Maximum Parsimony Methods. Molecular Biology and Evolution 28:27312739.

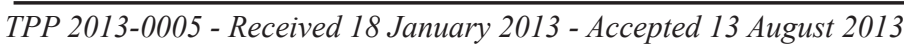
Section Editor: Silvaldo Felipe da Silveira 